\title{
Bilioduodenal anastomosis in rats with extra-hepatic biliary obstruction is followed by lesions ischemia and reperfusion-induced ${ }^{1}$
}

\author{
Lesão de isquemia e reperfusão em ratos com obstrução biliar extra-hepática \\ submetidos à anastomose bilio-duodenal
}

\begin{abstract}
Márcio Augusto Ferreira' ${ }^{\mathrm{I}}$, José Sebastião dos Santos ${ }^{\mathrm{II}}$, Robson Azevedo Dutra ${ }^{\mathrm{III}}$, Wilson Salgado Jr. ${ }^{\mathrm{IV}}$, Rafael Kemp ${ }^{\mathrm{V}}$, Camila Domiciano $^{\mathrm{VI}}$, Leandra N.Z Ramalho ${ }^{\mathrm{VII}}$,Ajith Kumar Sankarankutty ${ }^{\mathrm{VIII}}$,Orlando de Castro-e-Silva ${ }^{\mathrm{IX}}$

I Fellow Master degree, Department of Surgery and Anatomy, Ribeirão Preto Faculty of Medicine, University of São Paulo, Brazil.

II PhD, Professor, Division of the Digestive Surgery, Department of Surgery and Anatomy, Ribeirão Preto Faculty of Medicine, University of São Paulo, Brazil.

III MD, PhD, Department of Surgery and Anatomy, Ribeirão Preto Faculty of Medicine, University of São Paulo, Brazil.

IV MD, Professor, the Department of Surgery and Anatomy, Ribeirão Preto Faculty of Medicine, University of São Paulo, Brazil.

MD, Assistant, Division of the Digestive Surgery, Department of Surgery and Anatomy, Ribeirão Preto Faculty of Medicine, University of São Paulo, Brazil.

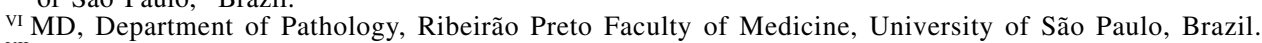

VII PhD, Professor, Department of Pathology, Ribeirão Preto Faculty Medicine, University of São Paulo, Brazil.

VIIIPhD, Professor, Division of the Digestive Surgery, Department of Surgery and Anatomy, Ribeirão Preto Faculty of Medicine, University of São Paulo, Brazil.

IX Full Professor and Head, Division of Digestive Surgery, Department of Surgery and Anatomy, Ribeirão Preto Faculty of Medicine, University of São Paulo, Brazil.
\end{abstract}

\begin{abstract}
Purpose: The aim of this study was to investigate alterations compatible with hepatic ischemia-reperfusion after bilioduodenal shunt (BD) in rats with obstructive jaundice (OB) . Methods: Thirty six animals were divided into 6 experimental groups: $\mathrm{CO} 1$ and $\mathrm{CO} 2$ - control groups, sham-operated (SO) and evaluated 6 and 24 hours after, respectively; OB1 and OB2,- obstructive jaundice groups, sham-operated 15 days after bile duct ligature and evaluated 6 and 24 hours after SO, respectively; DBD1and DBD2 - obstructive jaundice groups evaluated ,respectively, 6 and 24 hours after BD performed 15 days after bile duct ligature. The parameters evaluated were serum total bilirubin, aminotransferase activity (AST, ALT), $\mathrm{TNF} \alpha$, liver mitochondrial functions and parenchymatous injury. Results: Bilirubin decreased while aminotransferase activity increased 6 hours after $\mathrm{BD}(p<0.01)$; TNF $\alpha$ determination at the $6^{\text {th }}$ hour after BD was higher than the one at the $24^{\text {th }}$ hour $(p<0.05)$; oxygen consumption in states 3 and 4 remained elevated in the BD initial phase, and liver cell damage worsened 24 hours after BD. Conclusion: The results demonstrated that surgical biliary decompression in obstructive jaundice is followed by alterations related to hepatic ischemia- reperfusion.
\end{abstract}

Key words: Obstructive Jaundice. Biliary Obstruction. Cholestasis. Biliary Decompression. Ischemia-Reperfusion Damage. Secondary Biliary Fibrosis.

\section{RESUMO}

Objetivo: O objetivo do estudo foi investigar alterações compatíveis com o fenômeno de isquemia-reperfusão hepática em ratos com icterícia obstrutiva (OB) após derivação bilioduodenal (BD). Métodos: Trinta e seis animais foram divididos em seis grupos experimentais: CO1 e CO2 - grupos controle avaliados com 6 e 24 horas após operação simulada (SO), respectivamente; OB1 e OB2 - grupos com obstrução biliar, submetidos a SO 15 dias após ligadura do ducto biliar, e avaliados em 6 e 24 horas após a SO, respectivamente; DBD1 e DBD2 - grupos com 15 dias de obstrução biliar, avaliados em 6 e 24 horas, respectivamente, após BD. Os parâmetros avaliados foram bilirrubinas, aminotranferases (ALT e AST), funções mitocondriais hepáticas, dosagem de TNF $\alpha$ e lesão do parênquima hepático. Resultados: As bilirrubinas caíram após BD, enquanto as aminotransferases aumentaram 6 horas após $\mathrm{BD}(\mathrm{p}<0,01)$. O TNF $\alpha$ mensurado na $6^{\mathrm{a}}$ hora após a BD foi maior que o da $24^{\mathrm{a}}$ hora $(\mathrm{p}<0,05)$. O consumo de oxigênio no estado 3 e 4 mantiveram-se elevados na fase inicial do BD e as lesões celulares hepáticas agravaram-se na $24^{\mathrm{a}}$ hora pós BD. Conclusão: Os resultados demonstraram que a descompressão cirúrgica biliar na icterícia obstrutiva foi seguida de alterações que correspondem ao fenômeno de isquemiareperfusão hepática.

Descritores: Icterícia Obstrutiva.Obstrução Biliar. Colestase. Descompressão Biliar.Lesão de IsquemiaReperfusão.Fibrose biliar secundária.

1. Study performed at the Experimental Surgery Division, Department of Surgery and Anatomy, Ribeirão Preto Faculty of Medicine, University of São Paulo, Brazil. 


\section{Introduction}

Severe complications are usually associated to surgical treatment of obstructive jaundice. Hyperbilirubinemia, decreased glomerular filtration rate, fibrinogen degradation products, endotoxemia, low hematocrit and cancer ${ }^{1}$ are all associated with the morbidity and mortality rates ranging, respectively, from $20-70 \%$ and from $5-20 \%$ during the post-operative period ${ }^{2,3}$.

Experimental studies on extra-hepatic biliary obstruction have demonstrated a decrease in total hepatic flow $^{4}$ characterising a state of functional hepatic ischemia, which results from dilatation of the biliary ducts. ${ }^{5}$ Liver tissue hypoxia may cause cell injuries and enhance the deleterious effects from accumulated biliary salts and bilirubin.

Biliary decompression abruptly decreases portal vein pressure, increases portal blood flow and reduces both central venous and systemic arterial pressure. This fact suggests that reperfusion can promote sequestering of fluids within the liver and consequent release of endogenous lipases and oxygen free radicals, which culminate into decreased plasmatic volume and hypotension. ${ }^{6}$

Interruption of blood flow into a certain organ followed by reperfusion can cause acute inflammatory responses resulting in significant cell injuries and organic dysfunction. Reperfusion following ischemia results in loss of endothelial sinusoids, microcirculatory damage, leukocytes and platelet adhesion, decreased blood flow, perpetuation of the ischemic process, and activation of Kupffer cells and neutrophils. ${ }^{7,8}$

Various inflammatory mediators produced by Kuffer cells play a key role in hepatic ischemia and reperfusion, including production of free radicals from lipid peroxydation and endothelial cell damage. Vasoconstriction, platelet aggregation, chemotaxia, and neutrophils adhesion to endothelial cells are common effects. Cytokines, such as TNF- $\alpha$ are also involved in the mediation of the inflammatory response - a finding observed both in animals with biliary obstruction ${ }^{9}$ and icteric patients. ${ }^{10}$

Thus, extra-hepatic cholestasis may reduce portal blood flow through extrinsic compression of the dilated biliary ducts, and consequently produce hepatic ischemia as well. By effectively re-establishing both portal and biliary flow, biliary anastomosis produces what is described as hepatic ischemia-reperfusion injury. These alterations may be involved in the post-operative side-effects resulting from biliary obstruction surgery.

The objective of this study was to determine blood and liver morphological, biochemical, inflammatory, and metabolic changes related to ischemia-reperfusion in rats with extra-hepatic biliary obstruction treated by bilioduodenal anastomosis.

\section{Methods}

Laboratory animals were handled in accordance with the ethical code for animal experimentation established by the Council for International Organizations of Medical Sciences (CIOMS). Thirty-six male Wistar rats raised in the
Central Animal House of the Ribeirao Preto Campus of the University of São Paulo, weighing around 250-300g were divided into six groups.

Groups $\mathrm{CO} 1$ and $\mathrm{CO} 2$, considered as controls were sham-operated whereas animals of groups OB1 and OB2 had obstructed biliary ducts by means of double surgical ligature using 5.0 Mononylon (ETHICON, USA) followed by section. Biliary obstruction was maintained for 15 days before the simulated operation. Groups DBD1 and DBD2 also having obstructed biliary ducts during 15 days, were submitted to side-to-side bilioduodenal anastomosis with continuous 5.0 Prolene suture (ETHICON, USA).

Blood samples were collected 6 hours after the surgical procedures from animals in groups $\mathrm{CO} 1, \mathrm{OB} 1$, and DBD1 and after 24 hours in groups CO2, OB2, and DBD2. Liver samples for energetic metabolism studies and histopathological analysis were obtained after animal euthanasia. The immunoenzymatic method (ELISA) was used to determine serum levels of total bilirubin (BT), alanine aminotransferase (ALT) and aspartate aminotransferase (AST) activities, and TNF $\alpha$.

Liver samples were fixed in $10 \%$ formaldehyde and when necessary stored in $70 \%$ alcohol or microcut and stained with hematoxilin and eosin. A quantitative technique gauged according to a four-level scale of ischemiareperfusion injury was used for histological evaluation. ${ }^{11}$

For mitochondrial activity determinations, liver samples stored in cold physiological saline were fragmented and homogenised before being submitted to differential centrifugation. Mitochondrial protein was determined spectrophotometrically. ${ }^{12}$ Oxygen consumption in mitochondria was determined in states- 3 and -4 respiration, which show respectively, mitochondrial energetic capacity and consumption by energised mitochondria in the absence of ADP for maintenance of the organelle's membrane. The respiratory control ratio (RCR) was obtained from the relationship between state -3 and state- 4 respiration rates.

\section{Statistical Analysis}

The results expressed as means were analysed by the Kruskal-Wallis test, whereas Dunn's test was employed for multiple comparisons at $P=0.05$.

\section{Results}

Total bilirubin in serum was high after biliary obstruction, but significantly reduced 24 hours after the biliary by-pass $(\mathrm{p}<0.01)$.

The animals undergoing biliary anastomosis had aminotransferase activity values significantly increased after 6 hours when compared to values at 24 hours later and also to $\mathrm{CO}$ and $\mathrm{OB}$ animals $(\mathrm{p}<0.01)$. Similarly, TNF- $\alpha$ levels at the $6^{\text {th }}$ hour following biliary decompression were significantly higher than at the $24^{\text {th }}$ hour $(\mathrm{p}<0.05)$. (Figure 1) 


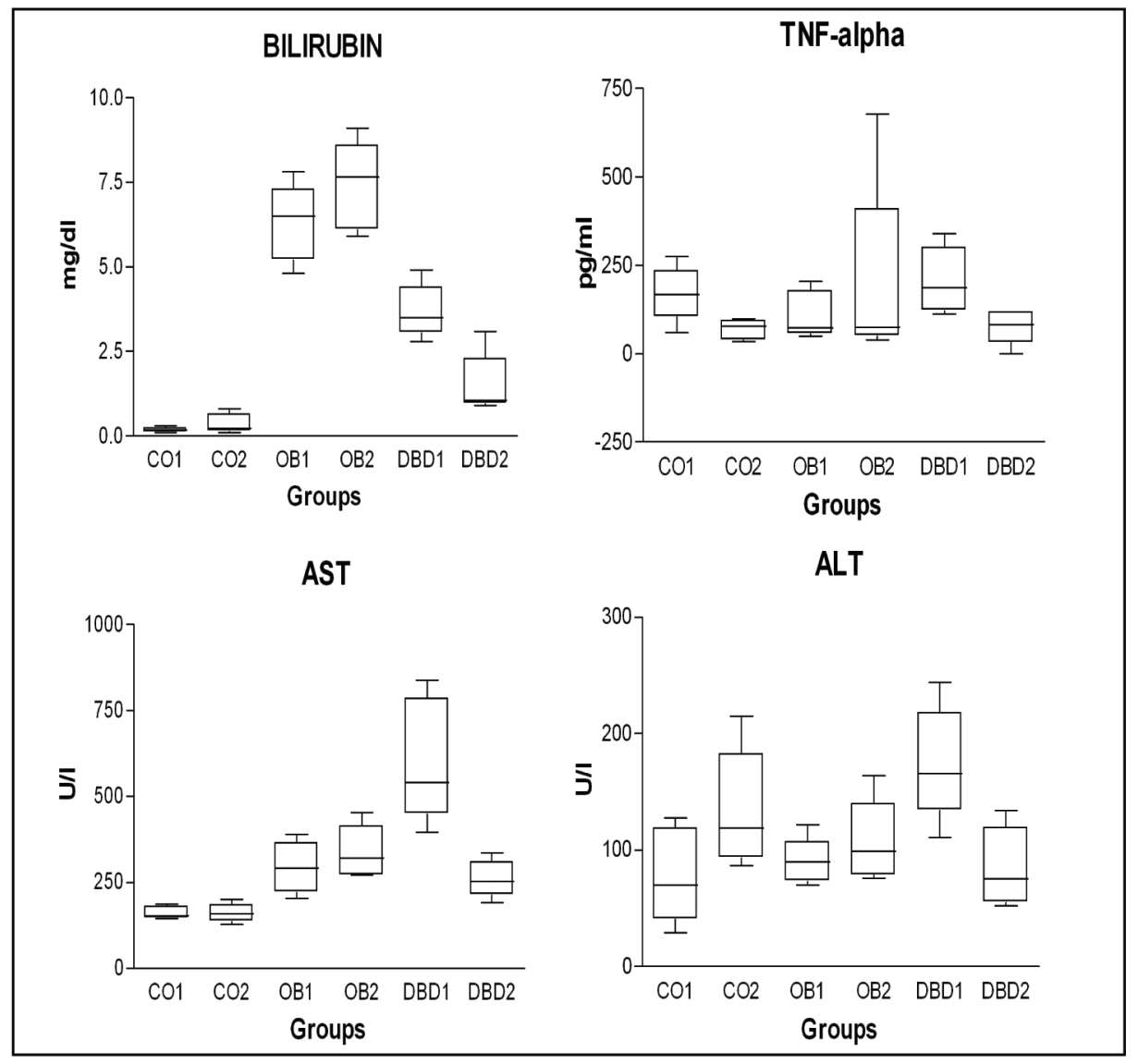

FIGURE 1 - Bilirubin in $\mathrm{mg} / \mathrm{dl}$, AST and ALT in UI, and TNF $\alpha$ in $\mathrm{pg} / \mathrm{mL}$ as means evaluated in: Controls, 6 (CO1) and 24 (CO2) hours, respectively, after sham-operation;

Rats with 15 days biliary obstruction evaluated at the $6^{\text {th }}$ hour (OB1) and at the $24^{\text {th }}$ hour (OB2) following simulated operation;

Rats with 15 days biliary obstruction submitted to bilioduodenal shunt at the $6^{\text {th }}$ hour (DBD1) and at the $24^{\text {th }}$ hour (DBD2) following surgical procedure.

Significant differences in:

bilirubin were found comparing: groups CO1xOB1/OB2/DBD1/DBD2; $\mathrm{CO} 2 \mathrm{x}$ OB1/OB2/DBD1/DBD2; OB1 X DBD2; OB2 x DBD1/DBD2; DBD1 x DBD2 (p<0.01); in AST between groups $\mathrm{CO} 1 \times \mathrm{OB} 1 / \mathrm{OB} 2 / \mathrm{DBD} 1 / \mathrm{DBD} 2$; $\mathrm{CO} 2 \times \mathrm{OB} 1 / \mathrm{OB} 2 / \mathrm{DBD} 1 / \mathrm{DBD} 2$; OB1 X DBD1; OB2 x DBD1; DBD1 x DBD2 ( $<<0.01)$;

ALT between groups CO1 x DBD1; OB1 X DBD1; DBD1 X DBD2 ( $<<0.01)$; and TNF-alfa between groups DBD1 X DBD2 $(p<0.05)$.

Oxygen consumption at basal (state -3) and active (state -4$)$ conditions was increased in animals with biliary obstruction when compared to the control group $(\mathrm{p}<0.01)$. The high oxygen consumption was kept at basal and active conditions 6 hours after biliary anastomosis, but decreased at the $24^{\text {th }}$ hour with no metabolic normalisation compared to the control animals $(\mathrm{p}<0.01)$ (Table 1). 
TABLE 1 - Mean and standard deviation values for oxygen consumption by mitochondria $\left(\mu \mathrm{MO}_{2} /\right.$ min.mg.prot. $\left.10^{-3}\right)$ in mitochondrial respiration states -3 and- 4 and for RCR in control and experimental groups rats evaluated at the $6^{\text {th }}$ hour $(\mathrm{CO} 1)$ and at the $24^{\text {th }}(\mathrm{CO} 2)$ hour following simulated operation; in animals with 15 days biliary obstruction evaluated at the $6^{\text {th }}$ hour (OB1) and at the $24^{\text {th }}$ hour (OB2) following simulated operation; and in rats with 15 day biliary obstruction submitted to bilioduodenal shunt at the $6^{\text {th }}$ hour (DBD1) and at the $24^{\text {th }}$ hour (DBD2) following surgical procedure.

Significant differences:

in state 3 were found between groups CO1 x OB1/OB2/DBD1; CO2 x OB1/OB2/DBD1; OB2 X DBD1; DBD1 x DBD2 ( $<<0.01)$;

in state 4 between groups CO1 x CO2/OB1/OB2/DBD1/DBD2; CO2 x OB1/OB2/DBD1/DBD2; DBD1 x DBD2 ( $<<0.01)$;

in RCR between groups $\mathrm{CO} 1 \times \mathrm{CO} 2 / \mathrm{OB} 1 / \mathrm{OB} 2 / \mathrm{DBD} 1 / \mathrm{DBD} 2$; $\mathrm{CO} 2 \mathrm{X}$ OB1/OB2/DBD1/DBD2 $(\mathrm{p}<0.01)$.

\begin{tabular}{cccc}
\hline Groups & STATE- 3 & STATE -4 & RCR \\
\hline CO1 & $68.67 \pm 11.01$ & $17.19 \pm 5.06$ & $4.2 \pm 1.14$ \\
CO2 & $51.37 \pm 9.98$ & $7.89 \pm 1.84$ & $6.58 \pm 0.67$ \\
OB1 & $131.71 \pm 21.2$ & $54.17 \pm 9.02$ & $2.47 \pm 0.47$ \\
OB2 & $112.96 \pm 14.85$ & $51.47 \pm 13.42$ & $2.28 \pm 042$ \\
DBD1 & $142.32 \pm 30.66$ & $75.56 \pm 18.26$ & $1.91 \pm .32$ \\
DBD2 & $83.35 \pm 21.68$ & $7.27 \pm 38.65$ & $2.14 \pm .18$ \\
\hline
\end{tabular}

Animals undergoing biliary obstruction for 15 days showed liver histological changes such as ductal proliferation and increased fibrotic deposits, indicative of, secondary biliary fibrosis. Histological alterations were more severe after biliary by-pass, mainly at the $24^{\text {th }}$ hour (Figure 2).

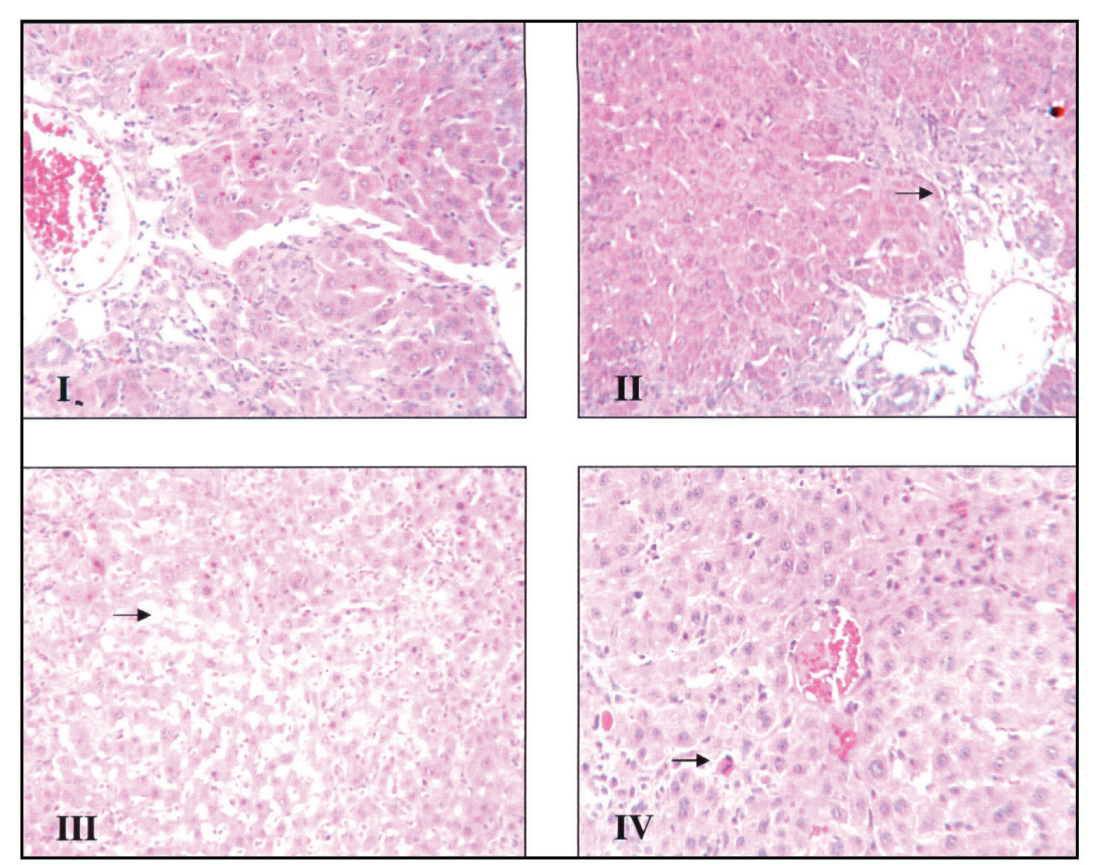

FIGURE 2 - Representative liver photomicrographs from:

I- animals with 15 days bile duct obstruction showing biliary proliferation and discrete fibrosis 24 hours after simulated operation (grade 0 ischemia-reperfusion);

II- animals with 15 days bile duct obstruction showing biliary proliferation, discrete fibrosis and neutrophil influx 6 hours after simulated-operation (grade 1 ischemia-reperfusion);

III- animals with 15 days bile duct obstruction, presenting biliary proliferation, discrete fibrosis, neutrophils influx, as well as microdroplet steatosis, 6 hours after bilioduodenal derivation (grade 2 ischemia-reperfusion);

IV- animals with 15 days bile duct obstruction presenting biliary proliferation, discrete fibrosis, neutrophils influx, as well as microdroplet steatosis, apoptosis and focal necrosis of hepatocytes, 24 hours after bilioduodenal derivation (grade 3 ischemia-reperfusion). Hematoxylin and eosin staining, original magnification $\times 200$ 


\section{Discussion}

Surgical procedures for biliary decompression in the treatment of extra-hepatic cholestasis are accompanied by high rates of complications and mortality ${ }^{1}$. It has been speculated that hepatic functional ischemia resulting from extra-hepatic cholestasis ${ }^{5}$ could be worsened following biliary decompression, resulting in ischemia-reperfusion injury that might be involved in post-operative complications.

The experimental model employed in the present study was found to be effective. Levels of total bilirubin initially elevated, gradually decreased after biliary anastomosis, thus, showing both the effectiveness of the cholestasis-inducing method as well as the role of decompression in re-establishing biliary excretion.

Aminotransferase activity levels were increased in animals with biliary obstruction compared to control animals. Six hours after biliary decompression, such values were found to be increased in relation to the OB group, but a significant decrease occurred after 24 hours. The increase in aminotransferase activity levels observed at the $6^{\text {th }}$ hour following biliary decompression indicates aggravation of pre-existing liver disease, which is in accordance with other experimental models of ischemia-reperfusion injury. ${ }^{13,14}$

The toxic action of bilirubin and biliary salts in extra-hepatic biliary obstruction, affects the respiratory chain decreasing both oxygen consumption and ATP synthesis, thus reducing the functional reserve. On the other hand, the portal blood flow decrease in association with an increase in metabolic demand may result in anoxia or functional hepatic ischemia. ${ }^{5}$

In this study, the activated mitochondrial consumption of oxygen was shown to be increased in the animals with biliary obstruction compared to the control group, which indicates metabolic hyperactivity during the period of energetic demand in an attempt to compensate ATP production. Six hours after the biliary by-pass, the already elevated oxygen consumption was maintained at basal and active conditions, with decreased RCR. Although it decreased 24 hours after, it was not accompanied by a metabolic normalisation.

Six hours after biliary by-pass serum TNF- $\alpha$ values were high when compared to the 24 hour ones. Although the cytokine is vulnerable to surgical stress and increases during the first 8 hours of the post-operative period, such an increase at the $6^{\text {th }}$ hour is suggestive of an exacerbated inflammatory state.

Activation of Kupffer cells results in TNF $\alpha$ production during the early phase of the ischemiareperfusion injury, which intensifies the inflammatory reaction. In fact, the cytokine has an active role in tissue injuries as it stimulates the production of other cytokines and acts directly upon the apoptosis of hepatocytes. ${ }^{15}$ In the present experiment, the increased production of TNF $\alpha$ 6 hours after biliary by-pass coincides with the findings that ischemia-reperfusion injury results, hours later, in neutrophilic infiltrates and apoptosis. In fact, considering the histological evaluation of liver, hepatic steatosis and presence of neutrophilic infiltrates were observed 6 hours after biliary by-pass, and worse injuries due to focal necrosis at the $24^{\text {th }}$ hour.

The significant increase in aminotransferase levels at the $6^{\text {th }}$ hour following biliary by-pass, in association with an increase in the basal and activated mitochondrial oxygen consumption, constantly low RCR, increased production of TNF $\alpha$ and worsened histological liver injuries, suggest that the hepatic parenchyma is susceptible to further injuries from biliary decompression. It is possible that hepatic parenchyma, in the cases of cholestasis, undergoes hipoxia due to vascular compression resulting from dilatation of the biliary ducts and that biliary decompression worsen inflammatory conditions related to the isquemia-reperfusion injury.

The results in this report contribute to the understanding of mechanisms possibly involved in the elevated rates of morbidity and mortality following surgical treatment of obstructive jaundice. In addition, future studies to minimise changes resulting from ischemia-reperfusion injury as well as better post-operative outcomes are expected to be continuations of the present investigation.

\section{References}

1. Dixon JM, Armstrong CP, Duffy SW, Davies GC. Factors affecting morbidity and mortality after surgery for obstructive jaundice: a review of 373 patients. Gut. 1983;24:845-52.

2. Kimmings AN, Van Deventer SJ, Obertop H, Rauws EAJ, Gouma DJ. Inflammatory and immunologic effects of obstructive jaundice: Pathogenesis and treatment. J AM Col Surg. 1995; 181(6):567-81.

3. Nakeeb A, Pitt HA. The role of preoperative biliary decompression in obstructive jaundice. Hepatogastroenterology. 1995; 42:332-7.

4. Mathie RT, Nagorney DM, Lewis MH, Blumgart LH. Hepatic hemodynamics after chronic obstruction of biliary tract in dog. Surg Gynecol Obstet. 1988;166:12530.

5. Roselino JE, Castro e Silva JR O, Ceneviva R. Lack of control of liver gluconeogenesis in cholestatic rats with reduced portal blood flow. Hepatology. 1992;16:105560.

6. Sterr ML. Chronic biliary obstruction: hemodynamic effects of decompression. Surg Forum. 1968;19:342-4.

7. Caldwell-Kenkel JC, Thurman RG, Lemasters JJ. Selective loss of nonparenchymal cell viability after ischemic stroge of rat livers. Transplantation. 1988;45:834-7.

8. Cywes R, Brandan J, Mullen M, Stratis MS, Greig Pd, Levy GA, Harvey PR, Strasberg SM. Prediction of outcome of transplantation in man by platelet adherence in donor liver allografts. Transplantation. 1993;56:316-23.

9. Greve JW, Maessen JG, Tiebosch T, Buurman WA, Gouma DJ. Prevention of postoperative complication in jaundiced rats. Internal biliary drainage versus oral lactulose. Ann Surg. 1990;212:221-7. 
10. Hunt DR, Allison MEM, Prentice CRM, Blumgart LH. Endotoxemia, disturbance of coagulation and obstructive jaundice. Am J Surg. 1982;144:325-9.

11. Gayotto LCC, Leitão RM. Patologia do fígado Transplantado. In: Gayotto. Doenças do fígado e vias biliares. Ed. Atheneu, cap. 106, p. 1219- 35, 1999.

12. Kaplan RS, Pedersen PL, Characterization of phosphate efflux pathways in rat liver mitochondria. Biochem $\mathrm{J}$. 1983;212:279-88.

13. Cottart CH, Do L, Blanc MC, Vaubourdolle M, Descamps G, Durand D, Galen FX, Clot JP.
Hepatoprotective effects of endogenous nitric oxide during ischemia reperfusion in the rat. Hepatology. 1999;29:809-13.

14. Kobayashi H, Nonami T, Kurokama T, Takeuchi Y, Harada A, Nakao A, Takagi H. Role of endogenous nitric oxide in ischemia reperfusion injury in rat live. $\mathrm{J}$ Surg Research. 1995;59:772-9.

15. Colletti LM, Kunkel SL, Walz A, Burdick MD, Kunkel RG, Wilke CA, Striter RM. The role of cytokine networks in the local liver injury following hepatic ischemia reperfusion in the rat. Hepatology. 1996;23:506-14.

\section{Correspondence:}

José Sebastião dos Santos

Department of Surgery and Anatomy

Ribeirão Preto Faculty of Medicine, University of São Paulo

Av. Bandeirantes 3900,

Conflict of interest: none

14048-900 Ribeirão Preto, SP, Brazil Phone :

Phone: +55-16-9766-2020; Fax: +55-16-3602-2496

jsdsanto@fmrp.usp.br

How to cite this article:

Ferreira MA, Santos JS, Dutra RA, Salgado Jr. W., Kemp R, Domiciano C, Ramalho LNZ, Sankarankutty AK, Castro-e-Silva O. Bilioduodenal anastomosis in rats with extra-hepatic biliary obstruction is followed by lesions ischemia and reperfusioninduced· Acta Cir Bras [serial on the Internet], 2008; 23 Suppl 1. Available from URL: http://www.scielo.br/acb

\section{Comments:}

The experimental study in rats concerns lesions caused by ischemia -reperfusion in extra-hepatic biliary obstruction followed by bilioduodenal derivation. It is an adequate scientific investigation addressing all necessary requisites. The inflammatory process, a consequence of ischemia-reperfusion and the main objective of the study, was evaluated by serological determinations. The results, showing systemic anomalies caused by ischemia reperfusion after biliary decompression, despite their animal origin have direct clinical application and could be used in research on extra-hepatic biliary obstruction. Bibliographic references mention relatively recent important and related papers, which do not compromise the global presentation. Among the authors of this excellent study, are researchers of great experience which warrants its publication.

\section{José Joaquim Ribeiro da Rocha}

PhD, Professor, Division of Coloproctology, Department of Surgery and Anatomy, Ribeirão Preto Faculty of Medicine, University of São Paulo, Brazil.

Comments: In this well elaborated study in rats the authors obstructed the main biliary duct by a coledoc ligature with 5.0 mono nylon thread, originating a dilatation of the intra-hepatic biliary ways. According to the literature, the dilatation compresses the vascular system and develops a ischemic lesion, which in turn causes an acute inflammatory response, severe cellular lesions and organic dysfunction. After abrupt biliary decompression the portal blood flow increases, now free by the canalicular dilatation pressure decrease. The more efficient hepatic tissue irrigation induces a reperfusion lesion accompanied by severe cellular injury. Analyzing the graphs in Figure 1, that shows groups with 15 day biliary obstruction and the sham operated after 6 and 24 hours (groups OB1 and OB2), a significant increase in bilirubin ,TNFa and transaminase levels is observed. Similarly, the cellular respiration results shown in Table 1 indicate increased mitochondrial oxygen consumption characterizing an ischemic lesion. After surgical bilio-duodenal derivation, a reperfusion lesion is established, as demonstrated by groups DBD1 and DBD2, with increased levels of TNT_n, transaminases and respiration stages 3 and 4, 6 hours after decompression surgery. These values are considerably diminished 24 hours postsurgery with lesion improvement. This experiment shows that the animal mitochondrial oxygen consumption is increased in biliary obstruction as a hipermetabolic activity to compensate for ATP production during higher demand. The opportune histological examination showed duct proliferation and fibroblastic infiltration corresponding to secondary biliary cirrhosis and deterioration 24 hours after derivation with apoptosis and focal necrosis. The results in this study are important to demonstrate that obstructive icterus treated by decompression of the biliary ways produces ischemic-reperfusion injurious effects on hepatic tissues and cells . 